\title{
URGENSI ORGANISASI MAHASISWA GAYO PERANTAUAN SEBAGAI WAHANA AKULTURASI BUDAYA: SEBUAH TINJAUAN TEORI IDENTITAS SOSIAL
}

\author{
Sulistiani \\ Universitas Negeri Yogyakarta, Yogyakarta, Indonesia \\ sulistianiamaine@gmail.com
}

\begin{abstract}
Migrating is defined as a person's journey to another area to achieve the desired goal and staff. In the realm of education, many youths decide to go to other areas to get a good education and are under expectations for the next life. The sophistication of today's technology makes migrating not a complicated thing to be doing in the community, especially the youth in taking education in place of choice. Based on the phenomena that occur to the lives of teenagers to study, the formulation of the research problem is planned, how students are social relations with the people of Jogja while in overseas land within the scope of the organization, this aims to find the strategy of student organizations of social life in Jogja. The research method is qualitative with a descriptive approach, data sources are Gayo students who are active in ethnic-based student organization activities in Jogja, data collection techniques are interview, observation, and documentation methods. The research results show that ethnic-based student organizations, IMAGAYO and IPEMAHLUTYO, carry out various activities such as the Saman and Guel dance as a form of interaction with the people of Jogja and adapt themselves by following the habits, behaviour patterns and Javanese culture as the majority culture in Jogja.
\end{abstract}

Keywords: nomad, gayo ethnic, cultural acculturation, social identity

\begin{abstract}
Abstrak
Merantau diartikan sebagai perjalanan seseorang ke daerah lain guna mencapai tujuan yang diinginkan dan menetap sementara, dalam ranah pendidikan banyak pemuda yang memutuskan untuk pergi ke daerah lain guna mendapatkan pendidikan yang baik dan sesuai dengan harapan untuk kehidupan selanjutnya. Kecanggihan teknologi saat ini menjadikan merantau bukan hal yang rumit untuk dilakukan oleh masyarakat khususnya kaum pemuda dalam menempuh pendidikan di tempattempat pilihan. Berdasarkan fenomena yang terjadi dalam kehidupan para remaja untuk menempuh studi, maka disusun rumusan masalah penelitian yaitu bagaimana hubungan sosial mahasiswa dengan masyarakat Jogja selama berada di tanah rantau dalam lingkup organisasi, hal ini bertujuan untuk menemukan strategi organisasi mahasiswa dalam kehidupan sosial di Jogja. Metode penelitian yaitu kualitatif dengan pendekatan deskriptif, sumber data adalah para mahasiswa Gayo yang aktif dalam kegiatan organisasi kemahasiswaan berbasis etnik di Jogja, teknik pengumpulan data yaitu metode wawancara, observasi, dan dokumentasi. Secara keseluruhan hasil penelitian menunjukkan bahwa organisasi mahasiswa berbasis etnik yaitu IMAGAYO dan IPEMAHLUTYO melakukan berbagai kegiatan seperti tari Saman dan Guel sebagai salah satu bentuk interaksi terhadap masyarakat Jogja
\end{abstract}

Sejarah Artikel: Diterima 9 Agustus 2021 | Direvisi hingga 29 Agustus 2021 Diterima 14 September 2021| Publikasikan 29 September 2021 
dan menyesuaikan diri dengan cara mengikuti kebiasaan, pola tingkah laku dan budaya Jawa sebagai budaya mayoritas di Jogja.

Kata kunci: perantau, etnik gayo, akulturasi budaya, identitas sosial

\section{PENDAHULUAN}

Kata "merantau" adalah salah satu kata yang sangat erat kaitannya dengan budaya Minang. Gagal di tanah rantau dianggap jauh lebih baik daripada berdiam diri di daerah asal. Di era sekarang merantau menjadi suatu keharusan bagi generasi penerus, bukan hanya terhadap etnik Minang tetapi juga etnik lainnya seperti etnik Gayo yang masih tergolong minoritas di Indonesia. Gayo merupakan salah satu suku yang mendominasi di beberapa wilayah Aceh seperti kabupaten Aceh Tengah, Bener Meriah, Gayo Lues dan Aceh Tenggara.

Dalam menempuh jenjang studi, orang tua sangat berperan penting untuk membimbing dan menentukan sekolah yang akan ditempati. Kualitas dan pendidikan yang baik menjadi salah satu pembentuk kesadaran diri, perkembangan berpikir dan berperilaku seseorang. Untuk mendapatkan pendidikan yang diinginkan, pemuda tidak hanya berdiam diri di tempat tinggal mereka, tetapi harus menempati daerah lain demi mendapatkan pendidikan yang diimpikan. Di daerah perantauan mahasiswa memiliki tempat atau wadah yang didirikan khusus untuk satu etnik yang sama. Tempat ini dijadikan sebagai tempat tinggal sementara dan terbatas untuk beberapa individu saja yang biasa disebut dengan "asrama". Selain asrama, mahasiswa menjadikan kegiatan organisasi sebagai wadah komunikasi antar sesama etnik mahasiswa perantauan. Organisasi mahasiswa etnik Gayo di perantauan terdiri dari dua ikatan, yaitu Ikatan Pemuda Mahasiswa Lut Tawar Yogyakarta (IPEMAHLUTYO) dan Ikatan Mahasiswa Gayo Lues Yogyakarta (IMAGAYO). Organisasi ini menyatukan mahasiswa dalam satu ikatan dengan berbagai kegiatan dan rencana yang akan dilaksanakan pada masa yang akan datang, permasalahannya adalah bagaimana organisasi tersebut dapat memperlihatkan identitasnya terhadap budaya tuan rumah selama di perantauan.

Masyarakat hidup dengan kebudayaan, sehingga segala sesuatu yang terdapat dalam masyarakat juga ditentukan oleh kebudayaan yang dimiliki oleh masyarakat tersebut. Kebudayaan merupakan keseluruhan cara hidup suatu golongan masyarakat, bahkan terdapat nilai-nilai, serta aturan dalam sekelompok masyarakat yang menganut kebudayaan tersebut. Bercampurnya dua kebudayaan yang berbeda merupakan interaksi dari akulturasi. Sementara aksi sosial merupakan perilaku yang saling berinteraksi sehingga interaksi menjadi sangat penting dalam membentuk kebudayaan kolektif. Hasil interaksi dapat berupa kebudayaan yang didalamnya terdapat norma-norma sosial yang baru. Pada sisi lain, norma yang ada dapat membentuk perilaku sosial yang diakui dan diyakini sesuai dengan maksud dan tujuan yang hendak dicapai (Muhtadi, 2016, hal. 118).

Organisasi mahasiswa sebagai suatu sistem sosial yang berperan penting dalam menunjukkan identitas sosial masyarakat tuan rumah. Identitas sosial berkaitan dengan keterlibatan, rasa peduli dan juga rasa bangga dari keanggotaan dalam suatu kelompok tertentu Tajfel (dalam Sholichah, 2016, hal. 42). Identitas sosial juga merupakan bagian penting dari konsep diri, pribadi yang baik dapat mengurangi konflik dalam organisasi (Harwood, 2020, hal. 2). Bertahannya suatu organisasi tersebut juga akan melibatkan bagaimana mahasiswa dalam membuka diri terhadap budaya yang berbeda, selain hal itu,

\section{JURNAL KEWARGANEGARAAN}


keaktifan mahasiswa juga menjadi salah satu faktor pendukung terhadap berjalannya organisasi. Davis \& Newstrom (1985) berpendapat bahwa organisasi juga menimbulkan hubungan atau relasi antara orang ke orang, teknologi, pekerjaan dan sumber daya.

\section{METODE PENELITIAN}

Penelitian ini menggunakan pendekatan deskriptif kualitatif yakni suatu studi yang mengungkapkan fenomena atau keadaan setelah semua kejadiannya berlangsung. Penelitian ini dilakukan dengan teknik sampling yaitu purposive sampling yaitu pemilihan sampel secara khas berdasarkan pengetahuan khusus atau kriteria. Subyek dalam penelitian ini adalah mahasiswa Gayo yang terlibat dalam organisasi etnik Gayo, mahasiswa merupakan agen perubahan dan generasi penerus bangsa yang akan berperan pada pembangunan suatu negara, mahasiswa harus kritis terhadap berbagai perubahan dan mampu dalam bersaing di era global. Penelitian ini dilakukan melalui pengamatan fenomena yaitu bagaimana mahasiswa perantauan berakulturasi melalui organisasi berbasis etnik dengan budaya yang berbeda di tanah rantau.

Pengumpulan data sebagai data primer diperoleh melalui observasi dan wawancara secara mendalam. Sedangkan data sekunder dilakukan melalui kegiatan studi kepustakaan dengan mengumpulkan bahan yang bersumber dari buku, jurnal ilmiah, majalah, tabloid maupun koran yang relevan. Pengumpulan data menggunakan teknik observasi, wawancara, dan dokumentasi. Observasi dilakukan dengan pengamatan lokasi penelitian guna menjalani secara langsung atau tidak langsung suatu kegiatan tersebut, wawancara dilakukan secara langsung dengan responden yaitu mahasiswa Gayo yang tergabung dalam organisasi kemahasiswaan, sedangkan dokumentasi sebagai penguat data dari observasi dan wawancara. Teknik analisis data dalam penelitian ini yaitu menguraikan, menafsirkan serta menggambarkan data yang telah terkumpul secara sistematik. Creswell (2016) menyatakan bahwa dalam penelitian kualitatif, analisis data dilakukan dengan beberapa langkah yaitu pertama mempersiapkan data untuk diolah atau dianalisis, kedua merefleksikan maknanya secara keseluruhan, ketiga koding data, keempat mendeskripsikan tempat, orang, dan lain sebagainya dari proses koding yang kemudian akan dianalisis, kelima mendeskripsikan tema yang akan disajikan dalam laporan, keenam memaknai data.

\section{HASIL DAN PEMBAHASAN}

Organisasi adalah suatu sistem yang dilakukan dengan aktivitas secara terus menerus dari satu individu dengan individu lainnya dalam lingkup kelompok yang memiliki tujuan yang sama. Dalam organisasi memiliki empat unsur yaitu terdapat sistem, pola aktivitas, sekelompok orang dan tujuan dari organisasi tersebut (Gitosudarmo \& Sudita, 2014, hal. 1). Dari pernyataan Gitosudarmo \& Sudita tersebut, maka secara keseluruhan hasil penelitian mengenai urgensi organisasi mahasiswa Gayo perantau berbasis etnik dapat dirincikan sebagai berikut:

\section{Keaktifan Mahasiswa dalam Organisasi Berbasis Etnik}

Mahasiswa yang kuliah memiliki salah satu tujuan untuk mencapai suatu kesuksesan. Kesuksesan mahasiswa tidak hanya pada ranah akademik yang baik saja, 
tetapi juga dari kemampuan mereka dalam berinteraksi dan bersosial (Setiyawati, 2019). Keaktifan para pemuda dalam mempertahankan budaya lokal sangat dibutuhkan untuk menjaga kebudayaan nasional. Seperti halnya pembelajaran budaya yang sangat dibutuhkan untuk bisa meneruskan pengetahuan dan pendidikan mengenai budaya lokal diperlukan sejak dini di setiap daerahnya, karena budaya lokal bukan hanya berkenaan dengan seni seperti tari dan folklor saja, tetapi juga berkaitan dengan rumah adat, pakaian, bahasa, maupun adat istiadat dari setiap kebudayaan yang ada di Indonesia. Maka diperlukan hal yang serius dalam menanamkan pendidikan dan pengetahuan sejak dini agar kelak generasi penerus dapat memahami dan melestarikan budaya lokal tanpa menghilangkan esensi budaya lokal tersebut.

Keaktifan mahasiswa sebagai pelajar dapat dikategorikan aktif jika mahasiswa tersebut melakukan apa yang dipikirkan atau bertindak secara langsung, ketika hanya berpikir tanpa melakukan sesuatu maka hal tersebut belum dapat dikatakan aktif secara fisik. Hasil penelitian Fujiantari \& Rachmatan (2016) bahwa kecerdasan emosional mahasiswa yang aktif dalam organisasi lebih tinggi dibandingkan dengan mahasiswa yang tidak aktif. Kecerdasan emosional digunakan oleh mahasiswa yang sudah memasuki masa dewasa awal untuk menghadapi masa ketegangan emosional. Seseorang dapat mengelola emosinya dengan baik seperti memecahkan masalah kehidupan secara pribadi maupun yang berkaitan dengan manusia lainnya merupakan penerapan dari keterampilan kecerdasan emosional yang dimilikinya. Pengalaman hidup yang dialami oleh mahasiswa di perantauan akan membentuk karakter yang baru, mahasiswa harus bisa mengendalikan emosi untuk menghindari berbagai konflik yang tidak diinginkan, pengendalian emosi juga menjadi salah satu bentuk masa peralihan mahasiswa menjadi manusia yang dewasa. Tindakan mahasiswa dalam memecahkan permasalahan berbeda di setiap individu, hal ini dikarenakan setiap mahasiswa bertemu dan berinteraksi dengan individu yang tidak sama.

Keaktifan dalam organisasi akan memberikan relasi antara pikiran dan tindakan secara fisik dan mental. Menurut Haslam, et., al. (2020) agar identitas mereka diketahui oleh orang lain maka anggota dalam organisasi saling memberikan motivasi untuk meningkatkan keaktifan mereka, contoh motivasi yang diberikan seperti menjenguk teman yang sedang sakit, makan bersama di asrama, membantu teman yang sedang terkena musibah, membersihkan asrama dengan cara gotong royong. Tindakan seperti ini dapat meningkatkan rasa solidaritas antar anggota kelompok di dalam organisasi.

Organisasi berbasis etnik berbeda halnya dengan organisasi mahasiswa di tingkat fakultas atau universitas karena nyatanya setiap organisasi memiliki tujuan yang berbedabeda. IMAGAYO dan IPEMAHLUTYO merupakan organisasi etnik mahasiswa Gayo perantauan yang dibentuk dengan tujuan yaitu mempermudah komunikasi, menjalin silaturahmi, mempertahankan budaya lokal di tanah rantau, mempererat rasa kekeluargaan dan yang paling utama adalah agar nilai- nilai budaya daerah bisa tetap terjaga di tengah masyarakat yang heterogen. yang membedakan IMAGAYO dan IPEMAHLUTYO adalah kedua organisasi ini memiliki budaya yang berbeda walaupun dalam satu etnik yaitu Gayo, IMAGAYO sebagai organisasi khusus mahasiswa Gayo Lues sedangkan IPEMAH merupakan organisasi Gayo Lut.

Ikatan Pemuda Mahasiswa Lut Tawar Yogyakarta terdiri dari ketua umum, wakil ketua, sekretaris, bendahara dan dilengkapi dengan 5 divisi serta \pm 100 anggota aktif. Keaktifan mahasiswa dalam organisasi dapat dilihat dari berbagai kegiatan yang

\section{JURNAL KEWARGANEGARAAN}


dilakukan mahasiswa Gayo perantauan di Jogja, dengan adanya organisasi berbasis etnik mampu memperkuat mahasiswa dalam memperkenalkan identitas lokalnya kepada masyarakat luas, Ikatan Mahasiswa Gayo lues yang lebih memperkuat dan menekankan kepada identitas budaya seni Tari Saman. Hal ini sesuai dengan pernyataan Jenkins (Vu, Nguyen, Tanh, \& Chun, 2016, hal. 202) bahwa terdapat tujuh keunggulan dari organisasi berbasis etnis, salah satunya adalah mampu memperkenalkan atau mempromosikan kelompoknya atau etnis tersebut dengan baik. Seperti mahasiswa dalam organisasi IMAGAYO yang mempromosikan Saman kepada masyarakat di tanah rantau sebagai bentuk kegiatan yang dikelola oleh divisi kesenian, hal ini dilakukan dengan cara bersosialisasi seperti diadakannya penggalangan dana untuk korban Sinabung Sumatera Utara, kegiatan Saman tersebut dilakukan di daerah alun-alun kidul Jogja. Hal ini berkenaan dengan sikap peduli sosial mahasiswa terhadap masyarakat Indonesia, sikap peduli sosial diartikan sebagai tindakan yang selalu ingin memberi bantuan pada orang lain dan masyarakat yang membutuhkan (Suwardani, 2020). Penampilan tersebut bukan hanya sekedar mempromosikan Saman, tetapi juga mempromosikan etnik Gayo. Terlebih masyarakat Jogja juga tidak sepenuhnya mengetahui tentang etnik Gayo, sehingga mahasiswa memperkenalkan etniknya melalui interaksi langsung dengan masyarakat setempat dengan cara bercerita dan menjawab berbagai pertanyaan masyarakat terkait tarian yang dilakukan oleh organisasi IMAGAYO. Selain di Alun- Alun Kidul, mahasiswa Gayo juga menampilkan Saman di berbagai event yang diadakan di daerah lain selain Jogja.

Hal tersebut dilakukan agar tari Saman dapat bertahan dan lebih dikenal oleh masyarakat Indonesia khususnya dan masyarakat dunia pada umumnya. Mahasiswa terus melatih diri untuk mendapatkan hasil yang maksimal, yaitu satu minggu dua sampai tiga hari. Berbagai kendala yang dihadapi oleh mahasiswa tidak menjadi permasalahan besar untuk tetap bisa mempertahankan budaya lokal tari Saman, apabila dibandingkan dengan perjuangan masyarakat Gayo terdahulu dalam memperkenalkan tari Saman sampai diakui sebagai warisan budaya tak benda oleh UNESCO dengan melibatkan kerjasama, dukungan, serta komitmen dari semua elemen, komitmen dari masyarakat Gayo Lues, komunitas tari Saman, dan pemerintah Indonesia pada saat itu. Komitmen tersebut merupakan bentuk nasionalis masyarakat Gayo terhadap budaya lokal dalam menjaga keberadaan budaya Indonesia untuk mendukung eksistensi identitas bangsa Indonesia (SD, 2015, hal. 94). Menjaga budaya lokal berarti mencintai tanah air Indonesia, mencintai tanah air tercermin dari cara bersikap, berpikir dan bertindak untuk menunjukkan kesetiaan terhadap bangsa dan negara. Dalam konteks keindonesiaan, karakter harus bertumpu pada kecintaan dan kebanggaan terhadap bangsa dan negara dengan Pancasila, UUD 1945, Bhinneka Tunggal Ika dan Negara Kesatuan Republik Indonesia sebagai pilarnya (Suwardani, 2020).

Bagi mahasiswa sebagai generasi muda yang melanjutkan pendidikan di kota pendidikan yaitu Yogyakarta mempertahankan budaya lokal Gayo seperti tari Saman tetap dilakukan walaupun memiliki beberapa kendala. Beberapa kendala yang dihadapi yaitu pertama, faktor wilayah tempat tinggal. Tinggal di wilayah yang bukan mayoritas suku Gayo menyebabkan tari Saman tidak bisa dilakukan setiap hari seperti di daerah Gayo Lues itu sendiri, karena di daerah Gayo Lues setiap desa memiliki tari Saman. Kedua, faktor waktu yang berbeda- beda dari setiap mahasiswa. Hal ini dikarenakan setiap mahasiswa yang ikut dalam kegiatan tari saman memiliki jenjang pendidikan dan jadwal belajar yang berbeda- beda. Untuk mengatasi beberapa kendala tersebut, 
mahasiswa membuat jadwal latihan agar dapat menampilkan tarian dengan maksimal tetapi tidak mengganggu waktu belajar di kampus. Kemampuan mengatur waktu sangat dibutuhkan bagi mahasiswa karena harus bisa melaksanakan kewajiban dengan mengerjakan berbagai tugas yang diberikan oleh dosen serta mengikuti kegiatan belajar, dikarenakan tujuan utama mahasiswa merantau adalah mengenyam pendidikan di perguruan tinggi yang diimpikan. Sehingga, mahasiswa Gayo tetap memprioritaskan pendidikan di perantauan. Hal ini juga merupakan dari bagian implementasi karakter mahasiswa yaitu disiplin dan bertanggung jawab, mahasiswa bertanggung jawab atas sikap maupun perilaku mereka dalam melaksanakan tugas dan kewajiban sebagai mahasiswa dan anggota organisasi, identitas mereka sebagai mahasiswa harus bisa menyelesaikan kewajiban sebagai pelajar sedangkan sebagai anggota organisasi harus menampilkan tarian di event secara maksimal. Kerja keras mahasiswa untuk menampilkan tarian dengan maksimal menunjukkan bahwa segala sesuatu harus dilakukan secara sungguh-sungguh, mengatasi berbagai permasalahan serta menyelesaikan tugas sebaik-baiknya.

Dengan melihat sejarah dan kemauan yang kuat dari masyarakat Gayo dahulu menjadikan mahasiswa sebagai generasi penerus memiliki kesadaran akan pentingnya pelestarian budaya lokal, sehingga tari Saman tetap berada dalam diri walaupun berada di luar wilayah Gayo. Seni tari Saman merupakan adat istiadat masyarakat Gayo Lues yang asal usul atau sejarahnya masih terdapat banyak perspektif dan pemikiran yang berbeda-beda, sebagian besar sejarah tari saman diketahui berasal dari bagian Timur Tengah yang dibawakan oleh Syeh Saman yakni dianggap sebagai ulama yang dalam penyebarannya Syeh Saman menggunakan lirik dan pujian terhadap Tuhan. Heniwaty (2015, hal. 75) menyatakan tari Saman yang berasal dari Gayo memiliki simbol dari persaudaraan, pendidikan, keagamaan, sopan santun, kepahlawanan, kekompakan, dan kebersamaan. Tari Saman memiliki arti di setiap gerakan dan lebih kepada arah religius, karena pada umumnya masyarakat Gayo juga sangat kental dengan ajaran Islam. Anggota dalam tarian ini diwajibkan berjumlah ganjil karena Allah menyukai yang ganjil kemudian tarian ini hanya diperbolehkan bagi laki-laki. Miller (2004, hal. 221) berpendapat bahwa berpartisipasi dalam kegiatan tradisional memungkinkan seorang individu untuk mengekspresikan dan mengabadikan nilai-nilai komunitas sebagai miliknya sendiri.

Tarian merupakan suatu gerakan dari setiap anggota tubuh yang dipadukan dengan iringan nada dan lagu yang dilakukan secara individu maupun kelompok. Tari-tarian yang tercipta akan menjadi identitas lokal dari setiap kebudayaan yang ada. Setiap tarian tersebut memiliki keunikan, makna maupun fungsi dalam kehidupan masyarakat. Tari adalah bentuk ekspresi jiwa yang dipadukan dengan gerakan anggota tubuh. Setiap gerakan anggota tubuh dalam tarian memiliki arti yang sesuai dengan irama dan musik yang dimainkan, walaupun hanya gerakan berupa hentakan kaki, semuanya melambangkan makna dan arti penting dari tarian tersebut. . Salah satu sejarah tari Saman yang dituliskan dalam catatan Marcopolo sewaktu singgah di kerajaan pasai pada tahun 1292 disebutkan bahwa Marcopolo khawatir di satu malam karena mendengar suara orang yang riuh seperti berkelahi. Namun ternyata, ia melihat kegaduhan tersebut dari suara orang Gayo yang sedang memukul-mukul dada dikatakan bermain Saman di atas batang kelapa yang telah direbahkan (Bahry, Wanti, Lestari, Syai, \& Djuaeni, 2014). Berbeda halnya dengan IMAGAYO, organisasi IPEMAHLUTYO lebih menekankan pada budaya seni tari Guel. Tari Guel dimainkan dengan bilangan genap, terdiri dari 8 
atau 10 orang penari perempuan dan 2 penari laki-laki yang berperan sebagai elang dan gajah, tarian ini juga diiringi dengan pemusik yang masing-masing berperan memainkan alat musik seperti penepok, canang, gong, seruling dan penyanyi. Tari Guel merupakan tarian yang menceritakan tentang asal usul budaya Gayo itu sendiri.

\section{Identitas Etnik Gayo dalam Tinjauan Teori Identitas Sosial di Perantauan}

Identitas merupakan hal yang dinamis dan beragam. Artinya, identitas seseorang akan berubah menurut pengalaman hidup dan menyebabkan identitas tersebut akan menjadi lebih banyak atau lebih dari satu, dengan ini identitas bersifat statis (Samovar, Porter, \& McDaniel, 2010, hal. 185). Identitas dari setiap individu bisa sama dan berbedabeda, seperti identitas sebagai warga negara yang dimiliki oleh setiap individu yang tinggal dalam suatu negara, tetapi identitas sebagai seorang pelajar tidaklah dimiliki oleh setiap warga negara. Bahkan di satu waktu yang sama seseorang bisa memiliki lebih dari satu identitas seperti saya bisa menjadi orang tua sekaligus warga negara yang bertanggung jawab saat ini (Carr, 2021). Teori identitas sosial menekankan bahwa perilaku individu mencerminkan unit masyarakat yang lebih besar seperti kelompok, organisasi, budaya dan identifikasi individu dengan unit-unit kolektif akan menjadi suatu proses internal. Pada hakikatnya, individu terlahir dalam suatu kelompok sosial. Oleh sebab itu, keanggotaan yang diturunkan dalam suatu kelompok sosial menjadikan individu memperoleh identitas sosialnya, seperti identitas agama, etnis, organisasi sosial, dan sebagainya (Hamzah, Agoha, \& Silviani, 2019, hal. 33).

Menurut teori identitas sosial, orang cukup mahir mengembangkan cara sistematis untuk mengklasifikasikan diri (diakui) dan identitas yang ditentukan ke dalam kelompok atau demografi seperti usia, etnis, jenis kelamin, afiliasi agama, kelas sosial, dan kesepakatan ke dimensi lingkungan sosial seperti fungsi kerja dan organisasi keanggotaan. Beragam cara dilakukan para perantau agar dapat bertahan dan dapat mencapai apa yang diinginkan selama di tanah rantau. Salah satu hal yang paling dihindari oleh perantau adalah menciptakan suasana yang tidak nyaman bagi masyarakat atau konflik yang akan berujung pada gesekan sosial. Mahasiswa menerapkan karakter cinta damai yaitu segala perkataan maupun tindakan yang membuat orang lain nyaman, senang dan tentram atas kehadirannya selama di perantauan.

Umumnya masyarakat akan saling melindungi jika tidak terjadi konflik, sehingga untuk mencapai semua hal tersebut pada dasarnya mahasiswa perlu belajar menangani hubungan sosial dan penyesuaian diri sebelum merantau. Hubungan sosial cenderung dialami pada tahap remaja yaitu usia 12 hingga 18 tahun. Pada usia ini yang menjadi konflik dasar dari perkembangan identitas diri adalah konflik mengenai identitas dan kekacauan peran. Kegagalan dalam mengembangkan identitas diri membuat para remaja tidak yakin serta bingung menangani siapa dirinya dan bagaimana masa depannya. Menghadapi kekacauan dan kegagalan yang terjadi salah satunya dapat dilakukan dengan cara membuka diri. Sifat keterbukaan dalam berkomunikasi sangat mempengaruhi interaksi dan hubungan sosial mahasiswa dengan masyarakat sekitar. Komunikasi dan sifat saling keterbukaan yang terjadi secara terus menerus memberikan banyak manfaat bagi kedua budaya yang berbeda, mahasiswa mampu mempelajari bagaimana kehidupan masyarakat budaya Jawa seperti adat-istiadat, penggunaan tutur kata dan aturan dalam kehidupan bermasyarakat. Keterbukaan mahasiswa juga di imbangi dengan adanya sikap 
toleransi yakni dapat menghargai segala perbedaan etnis, agama, sikap maupun tindakan yang berbeda selama di perantauan.

Dunia yang transparansi menjadikan setiap manusia berada di zona yang penuh dengan kebebasan, pengaruh budaya luar dan akulturasi menjadikan salah satu penyebab untuk tetap mempertahankan budaya lokal, hal ini dilakukan agar budaya lokal agar tidak mudah diambil oleh masyarakat luar dan negara lain. Kebudayaan sebagai identitas nasional menunjukkan betapa kebudayaan adalah aspek yang sangat penting bagi suatu bangsa, karena jelas kebudayaan merupakan salah satu jati diri dari bangsa Indonesia (Nuraeni \& Alfan, 2012, hal. 26). Dimensi budaya mempengaruhi hampir seluruh aspek perilaku manusia, beragamnya suku akan menciptakan kebudayaan yang berbeda- beda pula (Dockery, 2012).

Partisipasi dari individu atau kelompok yang berbeda budaya dalam suatu masyarakat yang lebih mayoritas, tanpa ingin mengubah identitas budayanya sendiri adalah salah satu penyebab terjadi akulturasi (Liebkind, Mähönen, Varjonen, \& Jasinskaja-Lahti, 2016). Akulturasi yang terjadi menyebabkan suatu asimilasi yaitu interaksi yang terjadi antar budaya yang berbeda dalam jangka waktu yang lama dan berakhir pada suatu pengadopsian nilai budaya yang berbeda. Proses akulturasi terjadi ketika kelompok-kelompok individu dari budaya yang berbeda melakukan kontak secara terus menerus dan kemudian menghasilkan perubahan dalam pola budaya asli salah satu kelompok tersebut. Setiawan, Agung, Yufridawati, \& Irmawati (2017) menyatakan bahwa kontak budaya memiliki beragam bentuk yaitu:

1. adanya kontak sosial pada seluruh, sebagian atau antar individu di lapisan masyarakat;

2. kontak budaya pada saat situasi bersahabat dan bermusuhan;

3. kontak budaya antara kelompok yang menguasai dan dikuasai dalam segi budaya, ekonomi, teknologi, bahasa, agama, ilmu pengetahuan, kemasyarakatan dan kesenian;

4. kontak budaya antara jumlah masyarakat yang banyak dan sedikit;

5. kontak budaya antara sistem budaya, sosial dan fisik.

Sebagai mahasiswa kontak budaya lebih sering terjadi di kampus, sementara di lingkungan sekitar tempat tinggal pengadopsian nilai budaya Jawa yang ramah, lemah lembut, dan saling bertegur sapa sangat mudah ditiru oleh mahasiswa. Akhirnya perilaku ini menjadi suatu kebiasaan (Thaumaet \& Soebijantoro, 2019, hal. 122). Interaksi sosial tersebut dapat berjalan dengan baik ketika memiliki persepsi yang sama dan sepaham karena pada dasarnya satu masyarakat dengan masyarakat lain tidak memiliki budaya yang sama. Menurut Baron dan Byrne (dalam Sudirmanto, 2019) terdapat hal utama yang membentuk perilaku sosial seseorang yaitu:

1. jika lebih sering bergaul dengan orang yang memiliki karakter santun maka kemungkinan akan berperilaku seperti kebanyakan karakter santun tersebut, begitu juga sebaliknya;

2. perilaku sosial akan dipengaruhi oleh ingatan dan pikiran termasuk ide-ide, keyakinan dan pertimbangan yang menjadi dasar kesadaran sosial seseorang;

3. perilaku sosial yang dipengaruhi karena faktor lingkungan;

4. perilaku sosial yang dipengaruhi karena perbedaan etnis budaya yang mungkin terasa aneh ketika berada di lingkungan masyarakat yang berbeda etnis budaya.

\section{JURNAL KEWARGANEGARAAN}


Terkait dengan teori di atas maka proses akulturasi mahasiswa Gayo terintegrasi dengan penduduk tetap di Jogja yang dipengaruhi oleh faktor perilaku/karakteristik orang lain, faktor lingkungan dan tatar budaya sebagai tempat perilaku dan pemikiran sosial itu terjadi. Identitas kelompok dapat diakui ketika kelompok tersebut memiliki perbedaan dengan kelompok lainnya, sedangkan dalam teori identitas sosial masyarakat harus dapat mencerminkan kelompok yang lebih mayoritas. Identitas yang melekat pada diri seseorang mempengaruhi perilaku dan sikap seseorang dalam lingkungan sosialnya. Dasar dan acuan dalam berinteraksi setiap individu dan kelompok adalah dengan memahami individu lainnya, seperti bagaimana memperlakukan orang lain sesuai dengan identitas yang dimilikinya. Tidak memahami identitas seseorang atau pengidentitasan yang salah dapat menyebabkan terjadinya konflik antara satu individu dan kelompok dengan individu dan kelompok lainnya.

Hal inilah yang terjadi pada mahasiswa perantau di Jogja pada awal merantau mengalami culture shock atau gegar budaya yang biasa dirasakan perantauan karena tinggal di wilayah yang memiliki kebudayaan berbeda. Budaya pertemanan, kegiatan mengkonsumsi barang, dan sistem pergaulan adalah beberapa proses yang dialami mahasiswa saat merantau. Hal ini tidak dapat dipandang sebelah mata oleh para mahasiswa perantauan, karena perlu disadari bahwa saat ini mereka sedang berada di daerah yang berbeda dengan daerah asal mereka tinggal. Mahasiswa sebagai makhluk sosial perlu melakukan penyesuaian diri terhadap lingkungan baru dengan melakukan interaksi pada orang lain walaupun menyesuaikan diri dengan lingkungan baru bukanlah perkara yang mudah (Sholichah, 2016, hal. 41). Berbagai kesulitan yang dirasakan untuk dapat menyesuaikan diri dengan masyarakat yang mayoritas, seperti penggunaan bahasa, makanan, dan watak. Watak di sini diartikan sebagai kebiasaan mahasiswa yang menganggap bahwa orang Gayo itu lebih keras dibandingkan etnis Jawa yang penuh dengan kelembutan. Menyatukan kebiasaan pribadi dengan adat istiadat dari kebudayaan yang berbeda adalah sebuah proses adaptasi.

Dalam teori identitas sosial mahasiswa Gayo sebagai pendatang harus mencerminkan bagaimana pola perilaku dan sikap penduduk tetap di tanah rantau tanpa meninggalkan budaya asli, mahasiswa hanya perlu menyesuaikan diri agar keberadaannya diakui oleh penduduk sekitar. Perubahan sikap dipengaruhi oleh interaksi yang terjadi, kemampuan berpikir dan mengatur diri sendiri. Beragam Implementasi pendidikan karakter yang diterapkan oleh mahasiswa tidak terlepas dari nilai- nilai Pancasila. Mahasiswa berinteraksi dengan menerapkan karakter sopan santun dan tetap toleransi terhadap masyarakat sekitar, bekerja keras demi penampilan maksimal dari tari saman maupun tari guel yang akan memikat masyarakat sebagai penonton. Bertanggung jawab dengan identitas yang dimiliki sebagai mahasiswa dan sebagai anggota organisasi etnik, bertanggung jawab berarti mahasiswa tetap menyelesaikan tugasnya di perkuliahan tetapi tidak meninggalkan kewajiban untuk jadwal latihan tari saman. Identitas sosial mahasiswa Gayo juga terbentuk melalui perbandingan sosial. Perbandingan sosial menjadi salah satu proses yang dibutuhkan mahasiswa untuk membentuk identitas sosial dengan cara melihat orang lain sebagai objek perbandingan, seperti menilai sikap dan kemampuan mahasiswa di perantauan. Mahasiswa mengetahui adanya nilai-nilai karakter positif seperti tanggung jawab, kerja sama, kerja keras, toleransi, sopan santun, dan peduli sosial yang harus terus di implementasikan guna mewujudkan kehidupan tanpa konflik di daerah perantauan, hingga mahasiswa bisa terus melestarikan budaya lokal di perantauan. 


\section{SIMPULAN}

Organisasi mahasiswa berbasis etnik terdiri dari sekumpulan mahasiswa yang memiliki latar etnik yang sama dan organisasi ini kerap didirikan mahasiswa sebagai perwujudan dari identitas daerah yang berbeda dengan menunjukkan identitasnya. Dengan adanya organisasi maka mahasiswa dapat melakukan hal secara bersama-sama termasuk mendukung identitas sosial mahasiswa dengan masyarakat di tanah rantau. Penyesuaian diri membutuhkan suatu cara dan strategi tersendiri bagi setiap individu. Watak dan kepribadian yang berbeda-beda kerap kali menjadi penghambat dalam membuka ruang interaksi yang nyaman. Sifat saling terbuka dan toleransi merupakan beberapa hal yang mendorong terjadinya identitas sosial mahasiswa dengan masyarakat Jogja, mahasiswa perlu membuka diri dan mengikuti budaya yang lebih mayoritas serta mencerminkan bagaimana perilaku masyarakat lokal, beberapa organisasi mahasiswa Gayo seperti organisasi mahasiswa Gayo Lues IMAGAYO yang menyajikan tarian Saman di daerah Alun-Alun Kidul yang menjadi salah satu solusi bagi mahasiswa dalam berinteraksi dengan masyarakat tuan rumah secara langsung tanpa meninggalkan identitas aslinya. Interaksi ini terjadi dengan cara mahasiswa menceritakan mengenai etnis Gayo dan asal usul Saman kepada masyarakat. Selain itu, mahasiswa juga perlu menyesuaikan perilaku yang kurang baik seperti nada berbicara keras menjadi lemah lembut, sedangkan organisasi IPEMAH (perkumpulan etnik Gayo Lut) juga menampilkan berbagai kegiatan seperti tari Guel yang dikenalkan kepada masyarakat Jogja. Pentingnya penyesuaian perilaku antara mahasiswa dengan masyarakat sekitar juga salah satu cara menghindari terjadinya gesekan sosial atau konflik (cinta damai). Organisasi menjadi bagian dari salah satu faktor pendukung mahasiswa dalam menyesuaikan diri dengan lingkungan, menunjukkan identitas ke Gayo-an yang tidak semua mahasiswa bisa melakukannya secara individu.

\section{UCAPAN TERIMA KASIH}

Saya sangat berterima kasih kepada seluruh mahasiswa Gayo yang terlibat dalam penelitian ini, terima kasih sudah meluangkan waktu dan memberikan dukungan, informasi serta dorongan untuk ketuntasan artikel. Saya juga berterima kasih kepada masyarakat yang sudah membaca artikel saya, mohon maaf apabila ada kekurangan dan kesalahan dalam artikel yang sudah saya tulis, saya bersedia menerima saran dan kritik dari para pembaca agar artikel ini dapat menjadi lebih baik lagi.

\section{DAFTAR PUSTAKA}

Bahry, R., Wanti, I. D., Lestari, T., Syai, A., \& Djuaeni, I. (2014). Saman: Kesenian dari Tanah Gayo. Jakarta: Pusat Penelitian dan Pengembangan Kebudayaan Badan Penelitian dan Pengembangan, Kementerian Pendidikan dan Kebudayaan.

Carr, D. (2021). Personal Identity is Social Identity. Phenomenology and the Cognitive Sciences, 20(2), 341-351. https://doi.org/10.1007/s11097-020-09702-1

Creswell, J. W. (2016). Research Design Pendekatan Metode Kualitatif, Kuantitatif, dan Campuran (A. Fawaid \& R. K. Pancasari, Penerj.). Yogyakarta: Pustaka Pelajar.

\section{JURNAL KEWARGANEGARAAN}


Davis, K., \& Newstrom, J. w. (1985). Human Behavior at Work Organizational Behavior (6 ed.; A. Dharma, Penerj.). Jakarta: Erlangga.

Dockery, A. M. (2012). Do Traditional Culture and Identity Promote the Wellbeing of Indigenous Australians? Evidence from the 2008 NATSISS. In B. Hunter \& N. Biddle (Ed.), Survey analysis for Indigenous policy in Australia: Social science perspectives (Vol. 32, hal. 281-305). Canberra: ANU E Press.

Fujiantari, D., \& Rachmatan, R. (2016). Perbedaan Kecerdasan Emosional Pada Mahasiswa Yang Aktif dan Tidak Aktif dalam Organisasi Kemahasiswaan. Jurnal Psikohumanika, 8(2), 43-60.

Gitosudarmo, I., \& Sudita, I. N. (2014). Perilaku Keorganisasian. Yogyakarta: BPFE.

Hamzah, I. F., Agoha, C., \& Silviani, A. (2019). Membangun Identitas Sosial dalam Organisasi Mahasiswa Pascasarjana. Psycho Idea, 17(1), 32-41. https://doi.org/10.30595/PSYCHOIDEA.V17I1.4030

Harwood, J. (2020). Social Identity Theory. In The International Encyclopedia of Media Psychology (hal. 1-7). https://doi.org/10.1002/9781119011071.IEMP0153

Haslam, S. A., Haslam, C., Jetten, J., Cruwys, T., \& Dingle, G. A. (2020). Social Identity. The Wiley Encyclopedia of Health Psychology, 679-688. https://doi.org/10.1002/9781119057840.CH119

Heniwaty, Y. (2015). Tari Saman Pada Masyarakat Aceh Identitas dan Aktualisasi. Universitas Negeri Medan.

Liebkind, K., Mähönen, T. A., Varjonen, S., \& Jasinskaja-Lahti, I. (2016). Acculturation and Identity. In D. L. Sam \& J. W. Berry (Ed.), The Cambridge Handbook of Acculturation Psychology (2 ed., hal. 30-49). https://doi.org/10.1017/CBO9781316219218

Miller, C. R. (2004). Ethnic Organizations and the Maintenance of Tradition. In D. Stanley (Ed.), Folklore in Utah: A History and Guide to Resources (hal. 216-223). Colorado: University Press of Colorado; Utah State University Press.

Muhtadi, A. S. (2016). Perspektif Perubahan Sosial. Bandung: Pustaka Setia.

Nuraeni, H. G., \& Alfan, M. (2012). Studi Budaya di Indonesia. Bandung: Pustaka Setia.

Samovar, L. A., Porter, R. E., \& McDaniel, E. R. (2010). Komunikasi Lintas Budaya; Communication Between Cultures. Jakarta: Salemba Humanika.

SD, H. A. (2015). Analisa Diplomasi Budaya Indonesia Melalui Tari Saman Gayo Dalam Mengukuhkan Identitas Nasional Bangsa. Jurnal Hubungan Internasional, 4(1), 88-96. https://doi.org/10.18196/hi.2015.0069.88-96

Setiawan, I. M. B., Agung, I., Yufridawati, \& Irmawati, A. (2017). Akulturasi Kebudayaan pada Masyarakat di Wilayah 3T: Peran PKBM terhadap Perubahan Sosial Budaya Masyarakat. Jakarta: Pusat Penelitian Kebijakan Pendidikan dan Kebudayaan, Balitbang, Kemendikbud.

Setiyawati, Y. (2019). Regulasi Diri Mahasiswa Ditinjau Dari Keikutsertaan Dalam Suatu Organisasi. Empati-Jurnal Bimbingan dan Konseling, 6(1), 71-78. https://doi.org/10.26877/EMPATI.V6I1.4115 
Sholichah, I. F. (2016). Identitas Sosial Mahasiswa Perantau Etnis Madura. Jurnal Psikosains, 11(1), 40-52. https://doi.org/10.30587/PSIKOSAINS.V11I1.635

Sudirmanto, S. (2019). Perilaku Mahasiswa Rantau di Pekanbaru (Studi Kasus Mahasiswa Pelalawan). Jom Fisip, 6(11), 1-12.

Suwardani, N. P. (2020). "Quo Vadis” Pendidikan Karakter dalam Merajut Harapan Bangsa Yang Bermartabat (I. W. Wahyudi, Ed.). Denpasar: UNHI Press.

Thaumaet, Y. A., \& Soebijantoro, S. (2019). Akulturasi Budaya Mahasiswa Dalam Pergaulan Sosial di Kampus (Studi Pada Mahasiswa Program Studi Pendidikan Sejarah Universitas PGRI Madiun). AGASTYA: JURNAL SEJARAH DAN PEMBELAJARANNYA, 9(1), 113-124. https://doi.org/10.25273/AJSP.V9I1.3641

Vu, C. M., Nguyen, D., Tanh, D. B., \& Chun, J. (2016). Case Study of an Ethnic Community-Based Organization in the United States. Nonprofit and Voluntary Sector Quarterly, 46(1), 199-217. https://doi.org/10.1177/0899764016654220 